\title{
Masalah Kesehatan Mental pada Wanita Hamil Selama Pandemi COVID-19
}

\author{
Yosi Duwita Arinda ${ }^{1}$ dan Milla Herdayati ${ }^{2}$ \\ 1,2Fakultas Kesehatan Masyarakat, Universitas Indonesia, Depok, Indonesia \\ yosi.duwita@ui.ac.id¹, milla@ui.ac.id²
}

Diajukan 2 Januari 2021 Diperbaiki 9 Februari 2021 Diterima 12 Februari 2021

ABSTRAK

Latar Belakang: COVID-19 yang menyebar secara masif menimbulkan banyak manifestasi. Kelompok rentan seperti wanita hamil berisiko mengalami masalah kesehatan psikologis. Pembatasan sosial yang diterapkan menyebabkan kurangnya dukungan sosial bagi wanita hamil.

Tujuan: Untuk menelaah masalah kesehatan psikologis selama pandemi COVID-19 serta dampaknya bagi wanita hamil.

Metode: Metode dalam penulisan artikel ini adalah tinjauan literatur yang terdapat dalam database jurnal kesehatan yakni Lancet, PubMed, Tandfonline, dan Science Direct. Artikel terpilih berdasarkan free full text, open access, berbahasa Inggris, dan terbit tahun 2020.

Hasil: Hasil studi literatur melalui database menemukan 31 artikel di Lancet Global Health, 155 artikel di PubMed, 10 artikel di Tandfonline, dan 73 artikel di Science Direct. Artikel yang relevan dengan topik yakni 30 artikel. Wanita hamil cenderung mengalami peningkatan kecemasan yang dapat mengakibatkan pada gangguan psikologis diantaranya kecemasan, stress, insomnia, depresi ataupun post-traumatic stress disorder. Gangguan kesehatan psikologis selama kehamilan meningkatkan risiko pada janin berupa perkembangan janin yang buruk, kelahiran prematur, ataupun BBLR.

Kesimpulan: Wanita hamil menjadi kelompok rentan mengalami masalah kesehatan psikologis. Faktor yang mendasarinya yaitu akses pelayanan kesehatan terbatas, kurangnya dukungan sosial dari berbagai pihak, dan kekhawatiran akan kesehatan dirinya dan janin apabila tertular.

Kata Kunci: Kesehatan Mental; Gangguan Psikologis; Wanita Hamil; COVID-19

\section{ABSTRACT}

Background: COVID-19 which is spreading massively has many manifestations. Pregnant women as vulnerable group have greater risks of psychological problems. Social restriction leads to lack of support for pregnant women.

Objective: To review mental health problems and their impact on pregnant women during COVID-19 pandemic.

Method: This was a literature review study, where the database used were Lancet, PubMed, Tandfonline, and Science Direct. Selected articles were based on free full text, open access, written in English, and published in 2020.

Results: Thirty-one articles in Lancet Global Health, 155 articles in PubMed, 10 articles in Tandfonline, and 73 articles in Science Direct were collected. Articles relevant to the topic were 30 articles. Pregnant women experiencing an increasing crisis were likely to have psychological disorders including anxiety, stress, insomnia, depression or PTSD. These problems increased the risk to the fetus in the form of poor fetal development, premature birth, or LBW.

Conclusion: Pregnant women as avulnerable group during pandemic tend to get psychological health problems due to the limited access to health services, lack of social support, and concerns about their own and fetal health.

Keywords: Mental Health; Psychological Disorder; Pregnant Women; COVID-19 
PENDAHULUAN

COVID-19 saat ini menjadi sebuah pandemi yang terjadi di banyak negara di seluruh dunia (WHO, 2020). Berdasarkan data Worldometer per tanggal 07 Februari 2021, kasus COVID-19 yang terjadi di seluruh dunia terkonfirmasi sebanyak 106.684.623 jiwa dengan total kematian sebanyak 2.327.249 jiwa dan sebanyak 78.383 .960 jiwa dinyatakan sembuh. Sementara di Indonesia terdapat sebanyak 1.157.837 jiwa dengan total kematian 31.556 dan 949.990 yang dinyatakan sembuh (Worldometer, 2020). Hampir semua layanan kesehatan terdampak oleh penyakit ini, termasuk pelayanan kesehatan maternal dan neonatal baik secara akses maupun kualitas (Kemenkes RI, 2020).

Wanita hamil dan janinnya merupakan populasi berisiko tinggi selama wabah penyakit menular. Perubahan fisiologis dan mekanis pada kehamilan secara umum meningkatkan kerentanan terhadap infeksi, terutama jika sistem kardiorespirasi terpengaruh, dan dapat menyebabkan gagal napas pada ibu hamil (Dashraath et al., 2020).

Penelitian yang dilakukan di sebuah rumah sakit New York City yang sudah terafiliasi selama 2 minggu dari 13 Maret 2020 hingga 27 Maret 2020 menemukan sebanyak 43 wanita hamil yang dinyatakan positif COVID-19, dengan 14 orang tanpa gejala dan 29 orang dengan gejala (Breslin et al., 2020). Temuan klinis pada wanita hamil dengan COVID-19 bisa jadi atipikal dengan suhu normal dan leukositosis (Liu et al., 2020). Namun, sama seperti pasien yang bukan termasuk pasien hamil, dari 55 responden pasien hamil dengan COVID-19 ditemukan gejala di antaranya demam (84\%), batuk (28\%), dan dispnea (18\%). Selain itu, komplikasi ditemukan juga pada janin, yaitu keguguran atau lahir mati (2\%), Intrauterine Growth Restriction (IUGR) (9\%), dan persalinan kurang bulan (43\%), serta kematian neonatal (2\%) (Dashraath et al., 2020).

Meskipun semua orang berisiko tertular, ibu hamil merupakan kelompok yang lebih rentan terkena virus (Fakari \& Simbar, 2020). Kehamilan adalah keadaan imun yang terganggu, dan perubahan adaptif biologis selama kehamilan dapat membuat wanita lebih rentan terhadap infeksi virus pernapasan, seperti influenza, sindrom pernapasan akut parah (SARS), dan sindrom pernapasan Timur Tengah (MERS) (Luo \& Yin, 2020).

Pembatasan sosial mengakibatkan kurangnya dukungan sosial untuk banyak wanita hamil karena mereka terpisah dari orang yang mereka cintai (Ali \& Feroz, 2020). Dukungan sosial membantu wanita hamil dengan stresor kehidupan mereka. Dukungan sosial yang tidak konsisten merupakan salah satu faktor risiko yang signifikan untuk depresi pada wanita hamil (Negron et al., 2013). Dalam situasi normal diperkirakan secara global sekitar $10 \%$ ibu hamil menderita gangguan jiwa, terutama depresi dan bahkan lebih tinggi (16\%) di negara berkembang (Zeng et al., 2020). Hal ini dapat diperburuk selama pandemi COVID-19 ketika wanita hamil mungkin memiliki akses yang terbatas ke layanan kesehatan mental. Di Cina, sebanyak $5.3 \%$ ibu hamil mengalami gejala depresi, $6.8 \%$ mengalami kecemasan, $2.4 \%$ mengalami ketidaknyamanan fisik, 2,6 \% mengalami insomnia, dan $0.9 \%$ mengalami PostTraumatic Stress Disorder (PTSD) (Zhou et al., 2020).

Dibandingkan dengan wanita yang tidak hamil, wanita yang hamil mungkin memiliki lebih banyak kesempatan untuk kontak dengan tenaga kesehatan walaupun tetap masih sangat terbatas pada pandemic ini (Zhou et al., 2020). Periode kehamilan dan persalinan pada wanita menempatkan mereka pada kondisi yang rentan terjadinya gangguan psikologis, meskipun postpartum blues dan depresi telah jauh ada sebelum pandemi. Namun, selama pandemi ini keterbatasan 
Masalah Kesehatan Mental pada Wanita Hamil...

akses wanita hamil untuk mendapatkan pelayanan kehamilan dan dapat diperburuk oleh kurangnya dukungan sosial dan keluarga secara langsung dapat meningkatkan masalah kesehatan psikologis wanita hamil, dan belum banyak laporan atau literasi yang melaporkan hubungannya secara rinci (Bender et al., 2020).

Isolasi, sosial, dan perubahan ekstrim dalam kehidupan sehari-hari dapat meningkatkan risiko depresi di antara populasi yang rentan seperti wanita hamil. Oleh karena itu, sangat penting untuk menilai dampak psikologis dari wabah COVID-19. Penelitian dengan studi literatur ini bertujuan untuk menelaah lebih dalam terkait masalah kesehatan mental atau psikologis pada wanita hamil selama masa pandemi COVID-19. Tinjauan literatur ini diharapkan dapat bermanfaat dalam mengidentifikasi dan mengurangi risiko komplikasi kehamilan akibat masalah kesehatan mental atau gangguan psikologis pada wanita hamil serta mengetahui kesiapan wanita hamil dalam menjalani kehamilan di masa pandemi COVID-19.

METODE

Metode dalam penulisan artikel ini merupakan literature review dengan menggunakan referensi dari jurnal dan artikel mengenai masalah kesehatan psikologis pada ibu hamil sebagai dampak dari pandemi COVID-19. Database yang digunakan dalam penelitian ini yakni Lancet, PubMed, Tandfonline, dan Science Direct, serta website WHO dan Worldmeter. Seleksi dokumen menggunakan kata kunci yakni "maternal mental health" AND "COVID-19" $O R$ "psychological impact of pregnant woman AND COVID-19". Penelusuran literatur melalui database penulis menemukan 31 artikel di Lancet Global Health, 155 artikel di PubMed, 10 artikel di Tandfonline, dan 73 artikel di Science Direct. Jumlah artikel terpilih sesuai dengan kriteria inklusi terdapat 30 artikel. Artikel tersebut telah memenuhi kriteria yakni dipublikasikan di jurnal ilmiah, tersedia dalam free full text, open access, berbahasa Inggris, dan diterbitkan pada tahun 2020.

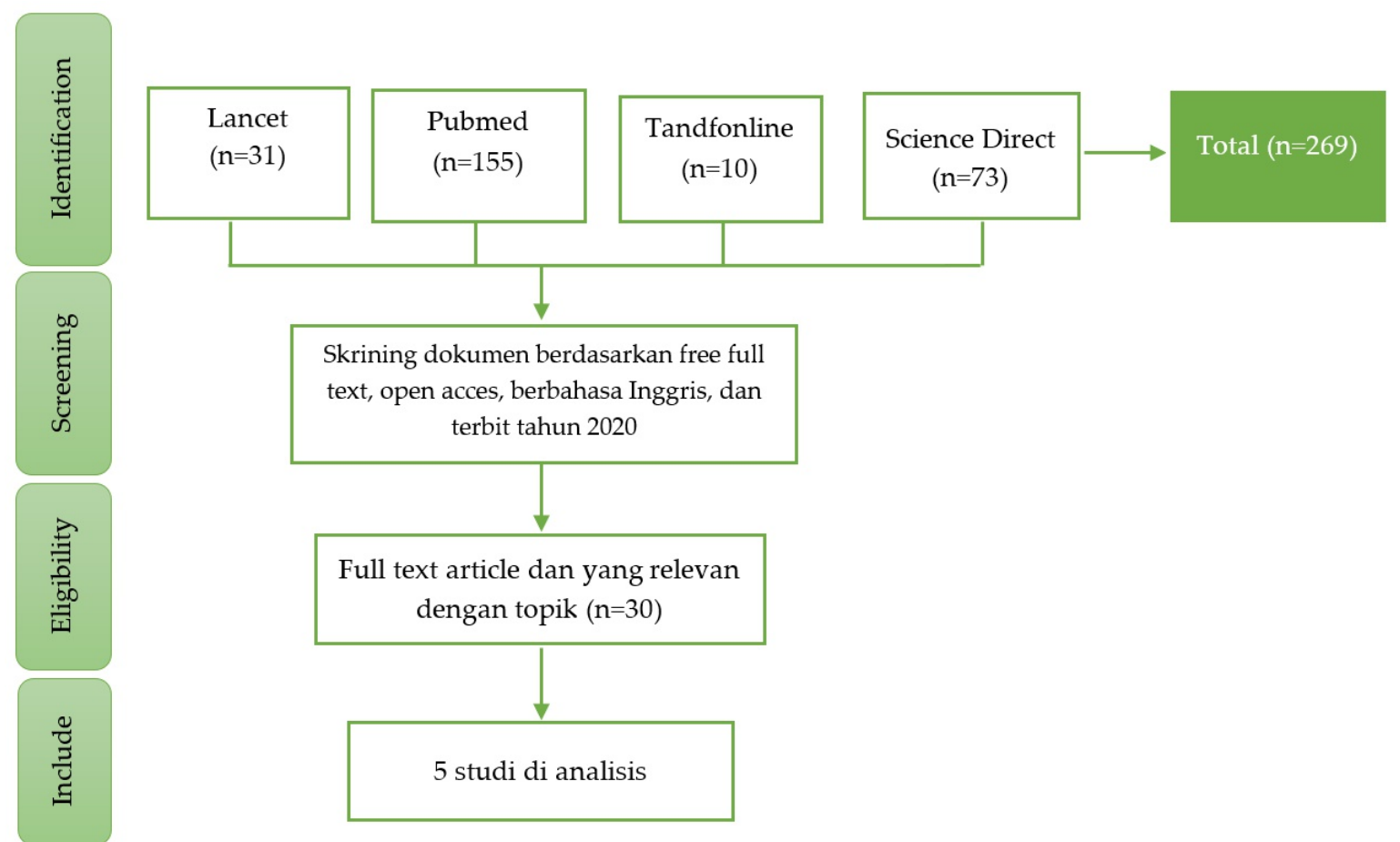

Gambar 1. Bagan hasil tinjauan literatur 
Masalah Kesehatan Mental pada Wanita Hamil...

Tabel 1. Ringkasan penelitian yang menggambarkan masalah kesehatan psikologis pada wanita hamil selama pandemi COVID-19

\begin{tabular}{|c|c|c|c|}
\hline No. & Penulis & Tahun & Kesimpulan \\
\hline 1 & $\begin{array}{l}\text { Whitney R. } \\
\text { Bender, et al }\end{array}$ & 2020 & $\begin{array}{l}\text { The Psychological Di antara } 310 \text { wanita, sebanyak } 34,4 \% \text { wanita } \\
\text { Experience of Obstetric multipara mengalami peningkatan kecemasan } \\
\text { Patients and Health Care pascamelahirkan dibandingkan dengan } \\
\text { Workers after persalinan sebelumnya karena kekhawatiran } \\
\text { Implementation of tentang paparan infeksi di rumah sakit dan } \\
\text { Universal SARS-CoV-2 kurangnya dukungan sosial. Oleh karena itu, } \\
\text { Testing } \\
\text { pandemi COVID-19 menempatkan pasien hamil } \\
\text { dalam posisi yang rentan terhadap kesehatan } \\
\text { mental. Kerentanan pasien hamil terhadap } \\
\text { kesehatan mental dapat diperburuk oleh } \\
\text { kurangnya interaksi dengan keluarga dan } \\
\text { dukungan sosial selama kehamilan, persalinan, } \\
\text { dan masa nifas. }\end{array}$ \\
\hline
\end{tabular}

2 Hern'an 2020 Mental health of pregnant Wanita hamil menunjukkan peningkatan depresi, LopezMorales, et al women during the kecemasan dan pengaruh negatif yang lebih jelas COVID-19 pandemic: A dibandingkan wanita yang tidak hamil. Selain itu, longitudinal study wanita hamil menunjukkan penurunan pengaruh positif yang lebih signifikan.

3 Gabriele 2020 Psychological impact of Saccone, et al

4 Yongjie Zhou, et al

5 Orit Taubman, et al coronavirus disease 2019 in pregnant women
Berdasarkan usia kehamilan, wanita pada trimester pertama kehamilan selama epidemi COVID-19 mengalami kecemasan yang lebih tinggi dan dampak psikologis yang lebih parah dibandingkan pada trimester kedua atau ketiga kehamilan.

2020 The prevalence of Selama epidemi COVID-19 di China, wanita psychiatric symptoms of hamil menghadapi masalah mental yang pregnant and non-disebabkan oleh COVID-19 yakni menunjukkan pregnant women during gejala depresi, kecemasan, insomnia, dan PTSD the COVID-19 epidemic yang lebih sedikit daripada wanita yang tidak hamil.

2020 Distress and anxiety Peningkatan gangguan kecemasan pada associated with COVID-kelompok rentan seperti wanita hamil dengan 19 among Jewish and Arab kekhawatiran terbesar muncul saat mereka pregnant women in Israel meninggalkan rumah, yaitu naik kendaraan umum atau berada di tempat umum, kekhawatiran tentang kesehatan orang lain, baik janin atau anggota keluarga, dan khawatir jika wanita hamil itu sendiri terinfeksi dan kecemasan tentang persalinan selama pandemic COVID-19.

\section{HASIL DAN PEMBAHASAN}

Artikel ini mengidentifikasi database berdasarkan beberapa kriteria, di antaranya jurnal atau artikel dapat di akses, full text, bahasa Inggris, dan terbit tahun 2020, yang diperoleh sebanyak 269 jurnal. Selanjutnya, berdasarkan judul diperoleh 30 studi yang relevan. Dari 30 studi yang relevan untuk dianalisis berdasarkan full text dihasilkan 25 artikel yang tidak eligible dan 5 artikel kemudian dianalisis.

COVID-19 merupakan penyakit menular baru yang disebabkan oleh sindrom pernapasan akut parah coronavirus 2 (SARS-CoV-2) (Capobianco et al., 2020). Pandemi COVID-19 menimbulkan risiko signifikan bagi kesehatan, termasuk kesehatan mental (Saccone et al., 2020). Sebagian besar studi tentang COVID-19 dan kaitannya dengan kehamilan telah dilakukan, hanya saja masih berfokus pada efek fisik pada wanita hamil yang terinfeksi dan kemungkinan penularannya. Akan tetapi, penting untuk tidak mengabaikan pengaruh dan keterlibatan emosional wanita hamil selama pandemi COVID-19, karena kesehatan mental ibu dapat dikaitkan dengan risiko jangka pendek 
dan jangka panjang bagi ibu dan janinnya (Kotabagi et al., 2020).

Beberapa penelitian telah melaporkan kerentanan ibu hamil terhadap ketidakstabilan emosi dan stres. Dengan demikian, kehamilan dapat menjadi faktor risiko yang dapat memperdalam efek negatif dari pandemi COVID-19 saat ini (López-Morales et al., 2021). Periode kehamilan dan persalinan pada wanita menempatkan mereka pada kondisi yang rentan terjadinya gangguan psikologis, meskipun postpartum blues dan depresi telah jauh ada sebelum pandemi. Namun, selama pandemi ini keterbatasan akses wanita hamil untuk mendapatkan pelayanan kehamilan rutin dapat diperburuk oleh kurangnya dukungan sosial dan keluarga secara langsung dapat meningkatkan masalah kesehatan psikologis wanita hamil (Bender et al., 2020).

Sebuah survei yang dilakukan di Cina menunjukkan bahwa 53,8\% responden mengalami dampak psikologis dari wabah tersebut dari sedang hingga parah, dan $28,8 \%$ melaporkan gejala kecemasan dan tingkat stres sedang hingga parah (Saccone et al., 2020). Gangguan kecemasan lebih sering terjadi pada wanita hamil $(39.0 \%$ vs $16.3 \%)$ dibandingkan wanita tidak hamil (Adewuya et al., 2006). Penelitian yang dilakukan oleh López-Morales et al. (2021) menunjukkan bahwa dalam rentang waktu 50 hari karantina, wanita hamil menunjukkan peningkatan depresi, kecemasan, dan pengaruh negatif yang lebih jelas dibandingkan wanita yang tidak hamil.

Dalam penelitian yang dilakukan oleh Wang et al., (2020), lebih dari separuh responden melaporkan gejala psikologis sedang hingga berat (kecemasan, depresi dan stres). Lebih lanjut, secara umum, perempuan dan kaum muda merupakan kelompok yang paling terkena dampak (Fullana et al., 2020).

Studi yang dilakukan di Italia

menunjukkan bahwa pandemi COVID-19 berdampak psikologis sedang hingga parah pada ibu hamil. Lebih dari dua pertiga wanita juga melaporkan kecemasan yang lebih tinggi dari biasanya. Hampir setengah dari wanita $(46 \%)$ melaporkan kecemasan tinggi terkait penularan penyakit secara vertical. Berdasarkan usia kehamilan menunjukkan bahwa wanita pada trimester pertama kehamilan selama epidemi COVID-19 mengalami kecemasan yang lebih tinggi dan dampak psikologis yang lebih parah dibandingkan pada trimester kedua atau ketiga kehamilan. Selanjutnya, dari 18 wanita yang melahirkan selama masa pandemi, sebanyak $16.7 \%$ melahirkan secara sesar yang direncanakan atas permintaan ibu. Hal ini terjadi karena kecemasan akan cedera janin atau kematian janin dan aspek emosional (Saccone et al., 2020).

Dalam situasi normal, diperkirakan secara global sekitar $10 \%$ ibu hamil menderita gangguan jiwa, terutama depresi dan bahkan lebih tinggi $(16 \%)$ di negara berkembang (Zeng et al., 2020). Hal ini dapat diperburuk dengan pandemi COVID-19 saat ini ketika wanita hamil mungkin mengalami hambatan terhadap akses ke layanan kesehatan mental. Di China, sebanyak 5,3\% ibu hamil mengalami gejala depresi, $6,8 \%$ mengalami kecemasan, 2,4\% mengalami ketidaknyamanan fisik, 2,6\% mengalami insomnia, dan 0,9\% mengalami PostTraumatic Stress Disorder (PTSD) (Zhou et al., 2020).

Pandemi COVID-19 yang menyebar secara massif di banyak negara membuat pemerintah memberlakukan tindakan untuk mencegah penyebaran virus tersebut dengan social distancing hingga lockdown. Isolasi, jarak sosial, dan perubahan ekstrim dalam kehidupan sehari-hari dapat meningkatkan risiko depresi di antara populasi yang rentan seperti wanita hamil (Saccone et al., 2020).

Social distancing mengakibatkan 
kurangnya dukungan sosial untuk banyak wanita hamil karena mereka terpisah dari orang yang mereka cintai (Ali \& Feroz, 2020). Dukungan sosial membantu wanita hamil dengan stresor kehidupan mereka. Dukungan sosial yang tidak konsisten merupakan salah satu faktor risiko yang signifikan untuk depresi pada wanita hamil (Negron et al., 2013). Pandemi COVID-19 juga telah membuat akses ke layanan umum menjadi terbatas, termasuk pelayanan kesehatan maternal dan neonatal, seperti ibu hamil yang menjadi tidak ingin ke fasilitas pelayanan kesehatan lainnya karena khawatir tertular, adanya anjuran menunda pemeriksaan kehamilan dan kelas ibu hamil, serta adanya ketidaksiapan pelayanan dari segi tenaga dan sarana prasarana termasuk Alat Pelindung Diri (APD) (Kemenkes RI, 2020). Perawatan dan penatalaksanaan ibu hamil merupakan layanan penting untuk mengidentifikasi ibu hamil yang berisiko tinggi (Goyal et al., 2020).

Kekhawatiran wanita hamil terkait postpartum blues dan depresi telah ada jauh sebelum pandemic sehingga perlu wanita hamil untuk datang ke fasilitas kesehatan, dan beinteraksi dengan tenaga kesehatan untuk mendapatkan pelayanan antenatal yang berkelanjutan. Pandemi menempatkan pasien hamil dalam posisi yang rentan. Selain kekhawatiran terjadi penularan virus melalui interaksi wanita hamil dengan tenaga kesehatan, kerentanan pasien hamil terhadap kesehatan mental yang merugikan dapat diperburuk oleh kurangnya interaksi dengan keluarga dan dukungan sosial selama kehamilan, persalinan, dan masa nifas dalam pandemi saat ini (Bender et al., 2020).

Selama kehamilan, wanita mungkin mengalami stres dan kecemasan yang terkait dengan kehamilan yang merugikan seperti kematian janin atau kelainan janin. Tingkat stres dan kecemasan juga dapat meningkat selama wabah penyakit menular (Saccone et al., 2020). Enam dari delapan wanita $(75 \%)$ yang dites positif melaporkan pengalaman negatif di rumah sakit akibat kurangnya dukungan penyedia dan pasangan dan pemisahan neonatal setelah lahir. Di antara 310 wanita, sebanyak $34,4 \%$ wanita multipara melaporkan peningkatan kecemasan pascamelahirkan dibandingkan dengan persalinan sebelumnya karena kekhawatiran tentang paparan infeksi di rumah sakit dan kurangnya dukungan sosial (Bender et al., 2020).

Dukungan sosial dapat dianggap sebagai strategi koping. Dukungan sosial dapat berasal dari sosial individu, seperti pasangan, teman, rekan kerja, maupun keluarga. Dukungan sosial secara signifikan dapat mengurangi efek merugikan dari kondisi stres untuk mencegah masalah mental bagi individu. Sebuah literatur menunjukkan bahwa dukungan sosial dikaitkan secara negatif dengan tekanan psikologis (Zhang et al., 2020).

Sejauh ini, COVID-19 telah menyebabkan ribuan kematian di seluruh dunia. Ketakutan dan dampak psikologis dari penyakit ini mungkin sama berbahayanya dengan infeksi. Kehamilan adalah periode perubahan besar (Saccone et al., 2020). Wanita perlu melakukan penyesuaian terhadap keadaan tersebut, karena hal ini dapat berpengaruh besar terhadap kondisi fisik dan terhadap psikologis seorang wanita yang pernah mengalaminya. Kehamilan bagi seorang wanita merupakan hal yang penuh kebahagiaan sekaligus kecemasan, yaitu cemas mengenai hal-hal buruk yang dapat menimpa dirinya dan janin

(Fourianalistyawati \& Caninsti, 2014).

Wanita hamil selalu dianggap sebagai populasi berisiko tinggi. Beberapa penelitian telah melaporkan bahwa wanita hamil rentan terhadap ketidakstabilan emosi dan stress. Pada saat yang sama, wanita hamil merupakan kelompok yang sangat rentan, mengingat dampak ganda 
pada mereka dan keturunannya (LópezMorales et al., 2021). Kondisi yang merugikan tersebut dapat menyebabkan terjadinya penyakit fisik dan mental pada bayi baru lahir dan dapat meningkatkan risiko persalinan prematur (Gemmill et al., 2019); (Hoffman et al., 2016), bahkan meningkatkan risiko kematian bayi (D'Onofrio et al., 2013). Selain itu, terdapat penelitian yang telah menemukan prevalensi gangguan mental yang lebih tinggi pada keturunannya (misalnya gangguan kecemasan), yang konsekuensinya dapat meluas dari masa kanak-kanak hingga remaja (LópezMorales et al., 2021). Gangguan emosional seperti depresi, kecemasan, dan stres ibu selama kehamilan berdampak pada bayi yakni perkembangan janin yang buruk, kelahiran prematur (preterm birth) dan bayi berat lahir rendah (BBLR). Anak-anak dengan preterm birth atau BBLR berisiko mengalami masalah emosional atau kognitif, termasuk hiperaktif, kecemasan, atau keterlambatan bahasa (Ibanez et al., 2015).

Dalam studi kohort prospektif terhadap 119 wanita hamil di sebuah klinik di Washington, DC, ditemukan bahwa tekanan psikologis ibu prenatal dikaitkan dengan gangguan perkembangan hipokampus janin selama trimester kedua dan ketiga akhir kehamilan dan perubahan gyrifikasi kortikal janin di lobus frontal dan temporal. Depresi ibu juga dikaitkan dengan penurunan kadar kolin dan kreatin di otak janin (Wu et al., 2020).

Penyediaan akses ke pelayanan kesehatan prenatal dengan membatasi paparan tenaga kesehatan dan pasien terhadap COVID-19 merupakan tantangan (Turrentine et al., 2020). Pada masa pandemi COVID-19 wanita hamil harus tetap melakukan pelayanan antenatal dan mengurangi serta mencegah terjadinya masalah kesehatan mental. Dalam meminimalisir penularan virus, beberapa upaya dapat dilakukan, seperti mengembangkan cara yang inovatif namun aman untuk memberikan dukungan dan perawatan yang dibutuhkan pasien selama masa pandemi ini. Penyedia layanan kesehatan dapat melakukan konsultasi telemedicine untuk meminimalkan paparan coronavirus (Bender et al., 2020).

Upaya yang dapat dilakukan agar wanita hamil tetap dapat melakukan perawatan prenatal dengan drive-through, yaitu ketika wanita hamil akan tetap berada di mobil mereka saat dinilai oleh profesional perawatan kesehatan, sehingga hal ini mengurangi potensi pasien, profesional perawatan kesehatan, dan staf yang terpapar COVID-19 (Turrentine et al., 2020). Kunjungan prenatal drive-through akan mencakup elemen-elemen pemeriksaan yang tidak dapat dilakukan melalui telehealth. Pelayanan drive-through mencakup pengukuran tekanan darah untuk evaluasi gangguan hipertensi pada kehamilan, pemeriksaan detak jantung janin, dan pengukuran atau observasi berbasis ultrasound. Pelayanan drive-through terdapat interaksi tatap muka pasien dengan tenaga kesehatan, sehingga dapat mengurangi kecemasan pasien akibat pengurangan jumlah kunjungan klinik yang dibatasi serta ketakutan wanita hamil akan pajanan virus di pelayanan kesehatan seperti klinik dan rumah sakit (Turrentine et al., 2020). Hal ini menunjukkan pentingnya penilaian kecemasan maupun gangguan terkait kesehatan mental lainnya pada wanita hamil selama pandemi COVID-19 (BenAri et al., 2020).

\section{KESIMPULAN}

Pandemi COVID-19 memberikan efek pada berbagai sector. Selain efek pada sistem kesehatan masyarakat dan ekonomi dunia, tindakan yang diterapkan dapat berdampak negatif pada kesehatan mental masyarakat. Wanita hamil merupakan kelompok rentan mengalami 
Masalah Kesehatan Mental pada Wanita Hamil...

gangguan emosional atau gangguan psikologis. Perubahan secara fisik dan fungsi hormon dapat memicu ketidakstabilan emosi wanita hamil. Kehamilan dapat menjadi faktor risiko yang dapat memperdalam efek negatif dari pandemi COVID-19 sehingga wanita hamil dapat mengalami peningkatan depresi, kecemasan dan pengaruh negatif yang lebih jelas dibandingkan wanita yang tidak hamil. Gangguan emosional seperti depresi, kecemasan, dan stres ibu selama kehamilan dapat berdampak pada janin di antaranya perkembangan janin yang buruk, kelahiran prematur, dan BBLR.

\section{DAFTAR PUSTAKA}

Adewuya, A. O., Ola, B. A., Aloba, O. O., \& Mapayi, B. M. (2006). Anxiety disorders among Nigerian women in late pregnancy: A controlled study. Archives of Women's Mental Health, 9(6), 325-328. https://doi.org/ 10.1007/s00737-006-0157-5

Ali, N. A., \& Feroz, A. S. (2020). Maternal mental health amidst the COVID-19 pandemic. Asian Journal of Psychiatry, 54, 102261. https://doi.org/10.1016/j.ajp. 2020.102261

Ben-Ari, O. T. -, Chasson, M., Abu Sharkia, S., \& Weiss, E. (2020). Distress and anxiety associated with COVID-19 among Jewish and Arab pregnant women in Israel. Journal of Reproductive and Infant Psychology, 38(3), 340-348. https://doi.org/ 10.1080/02646838.2020.1786037

Bender, W. R., Srinivas, S., Coutifaris, P., Acker, A., \& Hirshberg, A. (2020). The Psychological Experience of Obstetric Patients and Health Care Workers after Implementation of Universal SARS-CoV-2 Testing. American Journal of Perinatology, 37(12), 1271-1279.https://doi.org/10.1055/ s-0040-1715505
Breslin, N., Baptiste, C., GyamfiBannerman, C., Miller, R., Martinez, R., Bernstein, K., Ring, L., Landau, R., Purisch, S., Friedman, A. M., Fuchs, K., Sutton, D., Andrikopoulou, M., Rupley, D., Sheen, J.-J., Aubey, J., Zork, N., Moroz, L., Mourad, M., ... Goffman, D. (2020). Coronavirus disease 2019 infection among asymptomatic and symptomatic pregnant women: two weeks of confirmed presentations to an affiliated pair of New York City hospitals. American Journal of Obstetrics $\mathcal{E}$ Gynecology MFM, 2(2), 100118. https://doi.org/10.1016/j.ajogmf. 2020.100118

Capobianco, G., Saderi, L., Aliberti, S., Mondoni, M., Piana, A., Dessole, F., Dessole, M., Cherchi, P. L., Dessole, S., \& Sotgiu, G. (2020). COVID-19 in pregnant women: A systematic review and metaanalysis. European Journal of Obstetrics \& Gynecology and Reproductive Biology, 252, 543-558. https://doi.org/10.1016/j.ejogrb. 2020.07.006

D'Onofrio, B. M., Class, Q. A., Rickert, M. E., Larsson, H., Långström, N., \& Lichtenstein, P. (2013). Preterm Birth and Mortality and Morbidity: a population-based quasi-experimental study. JAMA Psychiatry, 70(11), 1231. https:// doi.org/10.1001/jamapsychiatry. 2013.2107

Dashraath, P., Wong, J. L. J., Lim, M. X. K., Lim, L. M., Li, S., Biswas, A., Choolani, M., Mattar, C., \& Su, L. L. (2020). Coronavirus disease 2019 (COVID-19) pandemic and pregnancy. American Journal of Obstetrics and Gynecology, 222(6), 521-531. https://doi.org/10.1016/ j.ajog.2020.03.021

Fakari, F. R., \& Simbar, M. (2020). Coronavirus Pandemic and Worries during Pregnancy; a Letter to Editor. Archives of 
Masalah Kesehatan Mental pada Wanita Hamil...

Academic Emergency Medicine, 8(1), $\quad$ e21. http:// www.ncbi.nlm.nih.gov/pubmed/ 32185371

Fourianalistyawati, E., \& Caninsti, R. (2014). Kualitas Hidup Pada Ibu Hamil Dengan Kehamilan Risiko Tinggi. Conference: Konferensi Nasional II Psikologi Kesehatan Universitas YARSI. https://osf.io/ 492ea/download/?format $=$ pdf

Fullana, M. A., Hidalgo-Mazzei, D., Vieta, E., \& Radua, J. (2020). Coping behaviors associated with decreased anxiety and depressive symptoms during the COVID-19 pandemic and lockdown. Journal of Affective Disorders, 275, 80-81. https://doi.org/10.1016/j.jad. 2020.06.027

Gemmill, A., Catalano, R., Casey, J. A., Karasek, D., Alcalá, H. E., Elser, H., \& Torres, J. M. (2019). Association of Preterm Births Among US Latina Women With the 2016 Presidential Election. JAMA Network Open, 2(7), e197084. https://doi.org/10.1001/ jamanetworkopen.2019.7084

Goyal, M., Singh, P., \& Melana, N. (2020). Review of care and management of pregnant women during COVID-19 pandemic. Taiwanese Journal of Obstetrics $\mathcal{E}$ Gynecology, 59(6), 791-794. https:// doi.org/10.1016/j.tjog.2020.09.001

Hoffman, M. C., Mazzoni, S. E., Wagner, B. D., Laudenslager, M. L., \& Ross, R. G. (2016). Measures of Maternal Stress and Mood in Relation to Preterm Birth. Obstetrics \& Gynecology, 127(3), 545-552. https://doi.org/10.1097/ AOG.0000000000001287

Ibanez, G., Bernard, J. Y., Rondet, C., Peyre, H., Forhan, A., Kaminski, M., Saurel-Cubizolles, M.-J., \& EDEN Mother-Child Cohort Study Group. (2015). Effects of Antenatal Maternal Depression and Anxiety on Children's Early Cognitive Development: A
Prospective Cohort Study. PloS One, 10(8), e0135849. https:// doi.org/10.1371/journal.pone. 0135849

Kemenkes RI. (2020). Pedoman Pelayanan Antenatal, Persalinan, Nifas, dan bayi baru lahir di Era Adaptasi Baru (Subdit Kesehatan Maternal dan Neonatal Direktorat Kesehatan Keluarga (ed.)). Kementerian Kesehatan RI. https://covid19.go.id/storage/app/ media/Materi Edukasi/2020/ Oktober/revisi-2-a5-pedomanpelayanan-antenatal-persalinannifas-dan-bbl-di-era-adaptasikebiasaan-baru.pdf

Kotabagi, P., Fortune, L., Essien, S., Nauta, M., \& Yoong, W. (2020). Anxiety and depression levels among pregnant women with COVID-19. Acta Obstetricia et Gynecologica Scandinavica, 99(7), 953-954. https://doi.org/10.1111/ aogs.13928

Liu, H., Liu, F., Li, J., Zhang, T., Wang, D., \& Lan, W. (2020). Clinical and CT imaging features of the COVID-19 pneumonia: Focus on pregnant women and children. Journal of Infection, 80(5), e7-e13. https://doi.org/10.1016/j.jinf. 2020.03.007

López-Morales, H., del Valle, M. V., Canet-Juric, L., Andrés, M. L., Galli, J. I., Poó, F., \& Urquijo, S. (2021). Mental health of pregnant women during the COVID-19 pandemic: A longitudinal study. Psychiatry Research, 295, 113567. https://doi.org/10.1016/j.psychres. 2020.113567

Luo, Y., \& Yin, K. (2020). Management of pregnant women infected with COVID-19. The Lancet. Infectious Diseases, 20(5), 513-514. https:// doi.org/10.1016/S14733099(20)30191-2

Negron, R., Martin, A., Almog, M., Balbierz, A., \& Howell, E. A. (2013). Social Support During the Postpartum Period: Mothers' 
Views on Needs, Expectations, and Mobilization of Support. Maternal and Child Health Journal, 17(4), 616-623. https://doi.org/ 10.1007/s10995-012-1037-4

Saccone, G., Florio, A., Aiello, F., Venturella, R., De Angelis, M. C., Locci, M., Bifulco, G., Zullo, F., \& Di Spiezio Sardo, A. (2020). Psychological impact of coronavirus disease 2019 in pregnant women. American Journal of Obstetrics and Gynecology, 223(2), 293-295. https://doi.org/10.1016/j.ajog. 2020.05.003

Turrentine, M., Ramirez, M., Monga, M., Gandhi, M., Swaim, L., TyerViola, L., Birsinger, M., \& Belfort, M. (2020). Rapid Deployment of a Drive-Through Prenatal Care Model in Response to the Coronavirus Disease 2019 (COVID-19) Pandemic. Obstetrics $\mathcal{E}$ Gynecology, 136(1), 29-32. https://doi.org/10.1097/AOG. 0000000000003923

Wang, C., Pan, R., Wan, X., Tan, Y., Xu, L., McIntyre, R. S., Choo, F. N., Tran, B., Ho, R., Sharma, V. K., \& Ho, C. (2020). A longitudinal study on the mental health of general population during the COVID-19 epidemic in China. Brain, Behavior, and Immunity, 87(January), 40-48. https:// doi.org/10.1016/j.bbi.2020.04.028

WHO. (2020). Coronavirus. WHO. https://www.who.int/healthtopics/coronavirus

Worldometer. (2020). Coronavirus Update (Live) - Worldometer. Worldometer.Info. $\quad$ https://
WWW.worldometers.info/ coronavirus/

Wu, Y., Lu, Y., Jacobs, M., Pradhan, S., Kapse, K., Zhao, L., Niforatosandescavage, N., \& Vezina, G. (2020). Association of Prenatal Maternal Psychological Distress With Fetal Brain Growth, Metabolism, and Cortical Maturation. JAMA Network Open, 3(1), 1-16. https://doi.org/10.1001/ jamanetworkopen.2019.19940

Zeng, L.-N., Chen, L.-G., Yang, C.-M., Zeng, L.-P., Zhang, L.-Y., \& Peng, T.-M. (2020). Mental health care for pregnant women in the COVID-19 outbreak is urgently needed. Women and Birth, January. https://doi.org/10.1016/j.wombi. 2020.03.009

Zhang, H., Tang, L., Ye, Z., Zou, P., Shao, J., Wu, M., Zhang, Q., Qiao, G., \& Mu, S. (2020). The role of social support and emotional exhaustion in the association between work-family conflict and anxiety symptoms among female medical staff: a moderated mediation model. BMC Psychiatry, 20(1), 266. https:// doi.org/10.1186/s12888-02002673-2

Zhou, Y., Shi, H., Liu, Z., Peng, S., Wang, R., Qi, L., Li, Z., Yang, J., Ren, Y., Song, X., Zeng, L., Qian, W., \& Zhang, X. (2020). The prevalence of psychiatric symptoms of pregnant and nonpregnant women during the COVID-19 epidemic. Translational Psychiatry, 10(1), 319. https:// doi.org/10.1038/s41398-02001006-x 